\title{
Teknik modelling simbolik dan reinforcement positif untuk meningkatkan keterampilan sosial pada anak Intellectual Disability
}

Karisma Dewi Puspasari, Universitas Muhammadiyah Malang, Malang, Indonesia

Korespondonesi:

Karisma Dewi Puspasari, Universitas Muhammadiyah Malang, Malang, email: krsmdw@gmail.com

\section{Riwayat artikel Naskah diterima: $22 / 02 / 2018$}

Revisi diterima: $09 / 06 / 2018$

Naskah disetujui: $20 / 06 / 2018$

\begin{abstract}
Abstrak
Subjek (15 tahun/ L) mengalami kesulitan dan keterlambatan dalam hal intelektual seperti membaca, menulis dan berhitung.Subjek juga mengalami kesulitan dalam berhubungan sosial.Asesmen dilakukan dengan menggunakan observasi, wawancara, tes psikologi dan tes intelegensi.Subjek memiliki masalah dalam keterampilan sosialnya.Hal itu disebabkan karena kurangnya contoh dan stimulus yang diberikan oleh lingkungan sekitarnya untuk dapat mengembangkan keterampilan sosialnya.Intervensi yang digunakan untuk menangani masalah subjek adalah dengan menggunakan reinforcement positif dan video modeling.Hasil intervensi menunjukkan terdapat perubahan yang positif pada diri subjek.subjek dapat berbicara dengan hati-hati sehingga perkatannya lebih jelas. Subjek juga sudah dapat mengajak temannya untuk berbicara dan menyapa temannya terlebih dahulu.Subjek berbicara dengan nada yang lebih tepat dalam setiap situasi.Hal ini menunjukkan bahwa intervensi yang dilakukan efektif untuk menangani masalah kurangnya keterampilan sosial pada subjek.

Kata kunci:intellectual disability, reinforcement positif, video modeling, anak
\end{abstract}

\section{Latar Belakang}

Disabilitas intelektual merupakan keterbatasan yang signifikan dalam berfungsi, baik secara intelektual maupun perilaku adaptif. Kriteria seseorang dapat disebut mengalami gangguan disabilitas intelektual antara lain (1) kurangnya fungsi intelektual seperti alasan, pemecahan masalah, perencanaan, berpikir abstrak, penilaian, pembelajaran akademik, dan belajar pengalaman; (2) kurangnya fungsi adaptif dalam memenuhi standar sosiokultural untuk mandiri dan memberikan respon sosial yang menyebabkan adanya hambatan komunikasi, partisipasi 
sosial, dan hidup mandiri di tengah lingkungan; (3) terhambatnya fungsi intelektual dan adaptasi selama masa perkembangan (APA,2013).

Keterbatasan fungsi adaptif dapat dinilai dari tiga area kemampuan, yaitu konseptual, sosial, dan praktis yang diperlukan seseorang dalam menjalankan kehidupan sehari-hari.Area konseptual meliputi keterampilan dalam berbahasa, membaca, menulis, matematika, penalaran, pengetahuan, dan memori.Area sosial meliputi empati, peniliaian sosial, dan kemampuan komunikasi interpersonal, sedangkan area praktis meliputi kemampuan perawatan diri.

Penyebab disabilitas intelektual dibagi menjadi dua yakni secara primer dan sekunder.Disabilitas intelektual primer disebabkan karena faktor keturunan (genetik). Sedangkan penyebab sekunder disebabkan karena faktor dari luar yang diketahui dan faktor-faktor ini mempengaruhi otak, baik pada waktu pranatal ataupun postnatal seperti gangguan metabolisme dan premeturitas dan dapat juga disebabkan oleh faktor-faktor yang lainnya.

Beberapa anak dengan disabilitas intelektual digolongkan sebagai anak yang mampu latih untuk beberapa keterampilan tertentu.Anak dengan disabilitas intelektual terkadang mengalami kesulitan ketika diminta berfungsi secara sosial atau akademis.Terkadang anak memperlihatkan rasa malu atau pendiam, namun hal ini dapat berubah bila anak dengan disabilitas intelektual banyak diikutkan untuk berinteraksi dengan anak lain (Henson \& Aller dalam Mangunsong, 2009).Salah satu simtom anak yang mengalami disabilitas intelektual adalah memiliki masalah dalam hal keterampilan sosial. Keterampilan sosial adalah kemampuan individu untuk berkomunikasi efektif dengan orang lain baik secara verbal maupun nonverbal sesuai dengan situasi dan kondisi yang ada pada saat itu, di mana keterampilan ini merupakan perilaku yang dipelajari (Hallahan \& Kauffman, 1988).

Keterampilan sosial sebagai perilaku-perilaku yang dipelajari, yang digunakan oleh individu pada situasi-situasi interpersonal dalam lingkungan.Keterampilan sosial, baik secara langsung maupun tidak membantu anak untuk dapat menyesuaikan diri dengan lingkungannya. Keterampilan sosial merupakan bentuk perilaku, perbuatan dan sikap yang ditampilkan oleh individu ketika berinteraksi dengan orang lain disertai dengan ketepatan dan kecepatan sehingga memberikan kenyamanan bagi orang yang berada disekitarnya (Gimpel \& Merrel, 1998).

Keterampilan sosial siswa berkebutuhan khusus umumnya berbeda sesuai dengan jenis kebutuhan khusus siswa.Ormrod (2009) menyatakan keterampilan sosial siswa berkebutuhan khusus dengan kesulitan kognitif atau akademis yang spesifik, masalah-masalah sosial atau perilaku, serta keterlambatan umum dalam fungsi sosial dan kognitif cenderung memiliki keterampilan sosial yang rendah.Keterampilan sosial siswa dapat diamati dengan memerhatikan beberapa aspek. Beberapa peneliti yang mengungkapkan aspek-aspek terkait dengan keterampilan sosial antara lain kerjasama, asersi, kontrol diri, tanggung jawab, dan empati (Gresham \& Elliot, 1990).

Beberapa indikator keterampilan sosial adalah berbicara dengan nada yang tepat, menjalin pertemanan dengan mudah, mengajak orang lain untuk ikut dalam suatu aktivitas, menyatakan ketidak setujuan, meminta izin ketika akan pergi, meminta bantuan ketika membutuhkan, tersenyum (Gresham \& Elliot, 1990).

Prinsip-prinsip behavior sesuai dengan permasalahan subjek dimana tidak ada stimulus yang membuat subjek dapat mengembangkan keterampilan sosialnya, baik dari keluarga, teman ataupun lingkungan sekitarnya. Ketika subjek mulai berinteraksi dengan lingkungan sekitarnya, subjek menemui penolakan, sehingga karena adanya penolakan tersebut, subjek lebih memilih untuk berdiam diri dirumah dan tidak berinteraksi dengan orang lain karena subjek tidak mendapatkan contoh perilaku dari lingkungan sekitarnya. Hal ini sesuai dengan prinsip social learning.Pada dasarnya manusia mempunyai kemampuan untuk berpikir dan mengatur atau mengarahkan diri sehingga dapat mengontrol lingkungan dan dibentuk 
oleh lingkungannya.Perilaku dipelajari individu melalui interaksi dengan lingkungan, dan perkembangan kepribadiannya tergantung pada interaksi tersebut (Hall \& Lindzey, 1981).

Intervensi yang sesuai diberikan pada subjek adalah menggunakan teknik modeling melalui video dan juga reinforcement positive.Intervensi ini dilakukan agar subjek dapat memahami keterampilan sosial yang harus dimilikinya dan karena pemberian penguatan positif dapat memperkuat tingkah laku baru yang dipelajari subjek (Corey, 2009).

\section{Metode Asesmen}

Asesmen yang dilakukan untuk mendapatkan informasi mengenai diri subjek dilakukan melalui wawancara, observasi dan tes psikologi.Wawancara dilakukan kepada subjek, keluarga subjek, serta guru di tempat subjek sekolah.Observasi dilakukan untuk mengamati perilaku subjek yang maladaptif. Tes psikologi yang digunakan adalah tes CPM untuk mengetahui grade intelegensi subjek. Tes VSMS untuk mengetahui fungsi adaptif subjek.

\section{Presentasi Kasus}

Subjek EFG adalah seorang anak laki-laki berusia 15 tahun.Berdasarkan tes intelegensi CPM, subjek berada pada kategori Intellectual Defective.Subjek saat ini berada di kelas 6 Sekolah Dasar.Karena adanya peraturan sekolah saat ini yang tidak memperbolehkan untuk tidak menaikkan siswanya, subjek selalu naik kelas.

Subjek tinggal bersama ibu dan ayahnya.Subjek memiliki 1 saudara laki-laki yang berusia 31 tahun.Ibu subjek mengandung subjek saat berusia 34 tahun.Ketika mengandung subjek, ibu subjek hampir tidak pernah makan dan hanya makan sedikit saja karena terpaksa. Ibu subjek ketika mengandung merasakan mual yang begitu luar biasa, sampai tidak ingin makan sama sekali. Subjek lahir pada saat usia kandungan 8 bulan 2 minggu atau 34 minggu dengan berat $2.1 \mathrm{~kg}$.

Sejak lahir subjek tidak pernah meminum ASI. Pada saat kecil subjek diberikan minuman susu kaleng dan juga biskuit bayi. Subjek merangkak dan mulai belajar berjalan pada usia 8 bulan. Subjek dapat berjalan sendiri pada usia 18 bulan. Pada saat Taman Kanak-kanak, subjek masih kesulitan bicara.Subjek hanya dapat mengatakan 1 kata saja. Hal tersebut subjek berada di taman kanak-kanak selama 3 tahun. Subjek baru dapat memakan nasi setelah subjek berada di TK.

Subjek baru memasuki sekolah dasar pada usia 8 tahun. Pada usia 8 tahun, subjek masih kesulitan untuk menulis dan membaca. Subjek biasanya kurang dapat menulis 1 kata dengan lengkap.Subjek memiliki hobi bermain sepak bola.Akan tetapi subjek jarang melakukannya.Dalam kesehariannya subjek sudah bisa mandiri dalam melakukan aktivitas kesehariannya seperti makan, mandi, memakai baju sendiri meskipun kurang rapi, dan bernagkat sekolah sendiri.

Menurut ibu dan ayah subjek, subjek adalah anak yang pendiam.Ketika berada dirumah subjek tidak banyak berbicara ataupun bercerita pada orangtuanya.Subjek juga tidak banyak berbicara pada saudaranya.Ketika bersama teman-temannya, subjek juga jarang berbicara.Subjek tidak banyak memiliki teman akrab di lingkungan rumahnya.Hal ini disebabkan karena semenjak kecil subjek tidak diperbolehkan oleh ibunya untuk sering bermain di luar dengan teman-temannya. Ibu subjek bersikap cukup protective pada subjek karena merasa takut subjek akan menjadi anak yang nakal karena menganggap banyak anak nakal yang ada di lingkungan rumah mereka.

Subjek yang jarang bermain di luar rumah, seringkali hanya bermain dengan ibunya saja.Ibu subjek bekerja sebagai pegawai di toko sedangkan ayah subjek bekerja sebagai pemulung sampah.Kedua orangtua subjek bekerja dari pagi sampai dengan sore hari.Sehingga ketika subjek pulang sekolah, subjek hanya berada dirumah sendirian. Yang dilakukan subjek ketika berada 
di rumah sendirian adalah menonton tv, tidur dan juga bermain handphone. Subjek jarang sekali keluar rumah dan bermain dengan teman-teman di sekitar lingkungan rumahnya.

Latar belakang pendidikan orangtua subjek rendah, ayah subjek merupakan lulusan Sekolah Dasar dan ibu subjek lulusan SMP.Latar belakang tersebut juga mempengaruhi pendidikan dan pengajaran yang diberikan pada subjek dirumahnya.Subjek yang membutuhkan pendidikan dan pengajaran yang lebih dari anak seusianya kurang mendapatkan pendidikan tersebut.

Subjek memiliki kematangan sosial dibawah usianya.Selain itu subjek juga memiliki kecenderungan hanya mengamati situasi sosial secara pasif.Menurut ibu subjek, ketika subjek diejek oleh teman-temannya di sekolah, subjek hanya diam saja.Subjek juga pernah dipukul oleh teman-temannya tetapi subjek hanya diam saja.Subjek tidak pernah mengatakan siapa yang mengejek dan memukulnya.Subjek juga tidak membalas perilaku teman-temannya yang mengejek dan memukulnya.Subjek merupakan seseorang yang kurang terbuka pada keluarganya tentang permasalahan yang dialaminya di sekolah.

Ketika dirumah subjek adalah seorang yang sangat penurut.Subjek tidak pernah menolak hal yang diberikan oleh ibu dan ayahnya. Meskipun subjek tidak menyukainya, subjek akan tetap menggunakannya. Subjek juga merupakan seseorang yang kurang tanggap atau kurang memiliki respon yang cepat. Subjek tidak akan membantu orangtuanya ketika tidak diminta. Ketika ada acara di rumah subjek, subjek juga tidak membantu apabila tidak diminta terlebih dahulu.Subjek lebih banyak diam saja.

Subjek berbicara dengan kurang jelas dan terdengar terburu-buru sehingga terkadang orang-ornag di sekitar subjek kurang memahami perkataan subjek. Ketika berbicara dengan orang lain subjek sering berbicara dengan nada yang tidak tepat. Seperti tiba-tiba bicara dengan nada yang tinggi, ataupun kemudian berbicara dengan sangat pelan.Hal tersebut terkadang membuat teman-teman subjek merasa bingung.Di sekolahnya, subjek jarang mengajak berbicara teman-temannya terlebih dahulu.Hal tersebut membuat subjek jarang bermain dengan teman-temannya karena jarangnya interaksi yang dilakukan dengan temannya. Ketika sedang berada di kelas, subjek tiba-tiba berdiri dan pergi ke kamar kecil. Hal ini membuat guru subjek kaget dan seringkali guru subjek meminta subjek untuk meminta izin terlebih dahulu jika ingin pergi ke kamar kecil.

Dalam hal perawatan dirinya, saat ini subjek sudah dapat melakukan perawatan dirinya secara mandiri seperti mandi, gosok gigi, dan juga menggunakan pakaian.Namun, dalam penampilan subjek sehari-harinya terlihat kurang rapi.Seperti rambut yang berantakan dan baju yang tidak dimasukkan kedalam dan tidak dikancingkan.

Hasil tes intelegensi subjek berada dalam kategori intellectual defective, yang berarti bahwa subjek mengalami kesulitan dalam hal-hal yang berhubungan dengan intelektual, seperti kesulitan menulis dengan lengkap, kesulitan membaca dengan cepat, kesulitan dalam berhitung.Kesulitan tersebut dialami subjek sejak masa perkembangannya dimana subjek baru bisa membaca dan menulis setelah berada di sekolah dasar.Subjek juga berada di Taman Kanak-kanak selama 3 tahun.

Kurangnya fungsi intelektual, kurangnya fungsi adaptif, dan terhambatnya fungsi intelektual dan adaptasi selama masa perkembangan dialami oleh subjek.Sedangkan permasalahan yang harus segera ditangani adalah kurangnya keterampilan sosial yang dimiliki oleh subjek.Dalam hal ini, subjek merasakan adanya perasaan aman ketika subjek menjauh dari lingkungan yang menolaknya, sehingga subjek cenderung bertahan dengan perilakunya tersebut dan tidak bisa mengembangkan keterampilan sosialnya.Untuk itu diperlukan intervensi video modeling dan reinforcement positif untuk meningkatkan keterampilan sosial subjek. 


\section{Diagnosis dan Prognosis}

\section{Diagnosis}

Hasil diagnosis subjek memenuhi kriteria DSM-5 untuk gangguan Intellectual disability dengan permasalahan kurangnya keterampilan sosial.

\section{Prognosis}

Prognosis positif karena subjek merupakan anak yang penurut dan lingkungan keluarga serta sekolah subjek mendukung subjek untuk adanya perubahan perilaku.

\section{Intervensi}

Intervensi yang digunakan untuk menangani subjek dengan masalah kurangnya keterampilan sosial pada anak dengan intellectual disability adalah dengan video modeling dan reinforcement positive. Penokohan (Modeling) adalah istilah yang menunjukan terjadinya proses belajar melalui pengamatan (observational learning) terhadap orang lain dan perubahan terjadi melalui peniruan. Peniruan (imitation) menunjukan bahwa perilaku orang lain yang diamati. Proses belajar melalui pengamatan menunjukan terjadinya proses belajar setelah mengamati perilaku pada orang lain

Modelling simbolik adalah model yang tidak dapat ditemui secara langsung oleh anak tetapi anak melihat model melalui media visual ataupun media audio visual (Charlop-Christy, Le, \& Freeman, 2001). Modeling simbolik ini dapat berupa gambar-gambar suatu tingkah laku yang mencerminkan sikap disiplin. Selain itu juga model simbolik dapat berupa tokohtokoh yang dilihat anak dalam acara TV, film animasi, video, cerita yang dapat menarik perhatian anak.

Sedangkan teknik reinforcement positif adalah pembentukan suatu pola tingkah laku dengan memberikan penguat atau reinforcement positif segera setelah tingkah laku yang diharapkan muncul merupakan suatu cara untuk mengubah tingkah laku (Corey, 2009).Positive reinforcement sebagai penyajian stimulus yang meningkatkan probabilitas suatu respon. Apabila suatu stimulus berupa benda atau kejadian itu dihadirkan (yang terjadi sebagai akibat atau konsekuensi suatu perilaku) secara berulang-ulang, sehingga keseringan munculnya perilaku tersebut meningkat atau terpelihara, maka peristiwa itu disebut positive reinforcement.

Prinsip umum dalam pemberian positive reinforcement adalah kesegeraan. Maksudnya bila perilaku yang telah diinginkan telah muncul dan akan dipelihara atau ditingkatkan maka segeralah diikuti dengan pemberian positive reinforcement. Bila ini dilakukan, maka frekuensi, besaran, dan kualitas perilaku tersebut akan dapat dipertahankan. Pemberian positive reinforcement memiliki prinsip - prinsip prosedur sebagai berikut. (a.) menyeleksi perilaku yang akan ditingkatkan. (b). Menyeleksi penguat. (c.) Menggunakan Penguat Positif. (Martin \& Pear, 2007).

Reinforcement positif yang diberikan dalam intervensi ini berupa hal yang disukai subjek.Pada awal pelaksanaan intervensi reinforcement positif telah disepakati oleh subjek dan terapis.Reinforcement yang digunakan adalah dengan memberikan makanan ringan yang sangat disukai subjek.Selain pemberian makanan riangan tersebut, reinforcement yang diberikan juga berupa penguat sosial yaitu pujian untuk subjek.

Pemberian video dilakukan sebelum subjek diminta untuk melakukan target perilaku yang diinginkan. Pemberian video ini bertujuan agar subjek dapat lebih memahami perilaku yang menjadi target intervensi. Selain itu pemberian video juga dapat menarik minat subjek.Setelah subjek melihat video, subjek diminta untuk menirukan target perilaku.Apabila subjek mau dan menirukan dnegan benar, maka subjek mendapatkan reinforcement berupa makanan ringan dan pujian.Modeling dilakukan melalui 4 tahapan yaitu atensi, retensi, reproduksi dan motivasi. 
Sesi 1: Menetapkan perilaku yang menjadi target. Pada sesi ini ditetapkan perilaku yang menjadi target intervensi yaitu meningkatkan keterampilan sosial pada subjek. Pada sesi ini terapis memberitahukan pada subjek untuk bersedia melakukan intervensi pada tahap-tahap selanjutnya agar subjek berkembang menjadi anak yang lebih baik.

Sesi 2: Menetapkanreinforcer dan model simbolik. Pada sesi ini ditetapkan reinforcer yang disukai subjek yaitu makanan ringan. Subjek menyetujui reinforcer yang digunakan adalah makanan. Terapis memberitahukan pada subjek bahwa subjek akan melihat video animasi anak pada pertemuan selanjutnya. Subjek memahami maksud terapis pada sesi ini dan tampak bersemangat untuk sesi berikutnya.

Sesi 3: Tahap Penerapan. Pada tahap ini dilakukan penerapan modeling simbolik dan teknik reinforcement positif yang diberikan sesaat setelah perilaku yang diinginkan muncul. Subjek ditunjukkan video selama 10 menit yang kemudian dilanjutkan dengan roleplay dan pemberian reinforcement positif apabila target terpenuhi. Tahap penerapan dilakukan sebanyak 5 kali pertemuan.Intervensi berjalan dengan lancar karena subjek yang penurut dan cukup memahami perkataan terapis.Saat melakukan modeling, subjek terlihat bersemangat ketika menonton video.Selanjutnya ketika dilakukan roleplay, subjek sering tampak malu-malu.Tetapi ketika intervensi berjalan beberapa kali, subjek tampak lebih nyaman.Subjek berhasil melakukan roleplay dari setiap model simbolik yang dilihatnya.

Sesi 4: Evaluasi. Pada tahap ini dilakukan evaluasi terhadap intervensi yang telah dilakukan.Pada tahap ini, terapis menilai apakah subjek dapat memenuhi target yang telah ditentukan.Subjek dapat berbicara dengan lebih jelas daripada sebelumnya dan telah berani menyapa temannya di sekolah.

Sesi 5: Menghentikan program. Ketika subjek mengalami perubahan perilaku, yaitu subjek sudah dapat berbicara dengan jelas dan lebih baik, intervensi dapat dihentikan dengan cara memberikan pengertian pada subjek bahwa subjek telah mengalami perubahan yang baik. Pada sesi ini, subjek cukup memahami terapis.Terapis juga mengatakan pada subjek bahwa subjek harus selalu berusaha untuk berbicara dengan baik dan menyapa temannya terlebih dahulu.

\section{Hasil dan Pembahasan}

\section{Hasil}

Intervensi dengan menggunakan teknik modeling dan reinforcement positive pada subjek dengan intellectual disability dapat meningkatkan keterampilan sosial pada subjek. Terdapat perubahan-perubahan yang dialami oleh subjek sesudah intervensi dilakukan.Berikut penjabaran hasil intervensi.

Intervensi dilakukan sebanyak 5 sesi. Penerapan program intervensi dilakukan dengan cara memperlihatkan video yang digunakan sebagai model simbolik terlebih dahulu. Hal tersebut bertujuan agar subjek mengerti dan memahami hal apa saja yang harus dilakukannya. Selanjutnya terapis meminta kepada subjek untuk menirukan hal tersebut, apabila subjek mau menirukan hal tersebut maka subjek diberikan makanan kesukannya. Reward yang diberikan kepada subjek sebelumnya telah disepakati dengan subjek dan subjek sangat menyukai makanan-makanan ringan. Video yang diperlihatkan pada subjek merupakan video gambar animasi yang berisi animasi anak-anak.Hal tersebut bertujuan agar subjek tertarik dan senang melihat video tersebut.

Selama proses intervensi dilakukan, intervensi berjalan dengan cukup lancar. Subjek yang merupakan seorang anak yang penurut selalu menuruti perkataan terapis sehingga intervensi dapat berjalan sesuai dengan rencana yang telah ditentukan dan dapat mencapai target yang diharapkan. 
Setelah melakukan intervensi, dengan cara melihat model yang ada di video kemudian mempraktikannya, subjek mengalami perubahan dalam beberapa hal, yaitu Subjek yang sebelumnya kurang bisa berkomunikasi dengan baik karena bicaranya yang kurang jelas, mencoba untuk berbicara dengan lebih hati-hati dan pelan-pelan sehingga kata-kata yang keluar dari subjek menjadi lebih mudah dimengerti. Tabel 1 menggambarkan perubahan perilaku setelah subjek memperoleh intervensi.

Selanjutnya, subjek yang sebelumnya jarang melakukan interaksi dengan teman-temannya dan cenderung lebih pasif dihadapan teman-temannya, setelah intervensi dilakukan subjek dapat menyapa temannya terlebih dahulu.Subjek juga dapat mengajak temannya untuk berbicara terlebih dahulu, meskipun terkadang subjek terlihat ragu-ragu.

Subjek yang sebelumnya berbicara dengan nada suara yang tidak tepat, misalnya dengan nada yang tiba-tiba pelan dan juga tiba-tiba keras, saat ini sudah dapat mengatur nada bicaranya. Sehingga, saat ini, cara berbicara subjek lebih baik. Dengan adanya perubahan pada nada bicara subjek, teman-teman subjek serta guru subjek dapat lebih mengerti perkataan subjek.Cara berbicara subjek juga terlihat menjadi lebih sopan jika berhadapan dengan orang yang lebih tua.

Perubahan lain yang dapat dilihat selain dari keterampilan sosial subjek adalah bahwa ketika keterampilan sosial subjek meningkat, terdapat beberapa hal positif lainnya yang dialami subjek seperti teman-temannya yang mulai lebih akrab dengannya serta guru dan orangtua yang dapat memahami keinginan dan perasaan subjek.

Pada saat follow up dilakukan, subjek saat ini telah dapat mengembangkan keterampilan sosialnya dengan mengajak temannya untuk bermain. Selain itu, menurut guru, subjek saat ini dapat lebih baik dalam berinteraksi dengan teman-temannya di kelas, sehingga saat ini subjek tidak sering berdiam diri.

Target intervensi ini adalah untuk meningkatkan keterampilan sosial subjek.Intervensi yang dilakukan cukup singkat, namun, subjek memiliki perubahan perilaku yang lebih positif dibandingkan sebelum dilakukan intervensi.Subjek dapat berbicara dengan lebih baik dan dapat menyapa temannya terlebih dahulu.

\section{Pembahasan}

Penerapan teknik video modeling efektif untuk meningkatkan keterampilan sosial pada anak dengan intellectual disability.Modeling menggunakan video dapat digunakan sebagai pembalajaran untuk anak dengan disabilitas intelektual untuk meningkatkan keterampilan-keterampilan dirinya (Horn et al. 2008; Rehfeldt, Dahman,Young, Cherry, \& Davis, 2003; Sigafoos et al., 2007).

Pemberian video dengan tujuan modeling pada anak dengan intellectual disability untuk meningkatkan keterampilan sosialnya dinilai efektif untuk meningkatkan keterampilan sosial anak-anak dengan intellectual disability.Melalui video tersebut, subjek dapat menggeneralisasikan keterampilan yang telah dipelajarinya melalui video pada lingkungan

Tabel 1. Perbandingan sebelum dan sesudah intervensi

\begin{tabular}{ll}
\hline Sebelum Intervensi & Sesudah Intervensi \\
\hline Subjek kurang bisa berkomunikasi dengan & Subjek mulai dapat berbicara dengan pelan \\
baik, subjek berbicara dengan kurang jelas. & dan hati-hati. \\
Subjek jarang berinteraksi dengan & $\begin{array}{l}\text { Subjek mulai dapat menyapa teman-temannya } \\
\text { teman-temannya (pasif). }\end{array}$ \\
$\begin{array}{ll}\text { Subjek sering bicara dengan nada yang tidak } \\
\text { tepat. }\end{array}$ & $\begin{array}{l}\text { Subjek dapat bicara sesuai dengan situasi yang } \\
\text { dihadapinya. }\end{array}$ \\
\hline
\end{tabular}


yang berbeda dan pada orang-orang yang berbeda pula dan subjek juga dapat melanjutkan keterampilan baru yang telah dipelajarinya setelah intervensi selesai (Avcioglu, 2013).

Modeling melalui video merupakan sebuah cara yang efektif untuk mempelajari kemampuan oral dan motorik, perilaku sosial, keterampilan sehari-hari dan juga bagaimana cara menghadapi masalah pada anak-anak dengan kebutuhan khusus (Nikopoulos and Keenan, 2006).

Pembelajaran melalui video merupakan jenis pembelajaran secara visual. Hal tersebut membuat target perilaku dideskripsikan secara jelas sehingga hal tersebut memberikan keuntungan jika dibandingkan dengan metode yang lebih tradisional. Hal tersebut memberikan kemungkinan bahwa pembelajaran akan lebih berguna dan lebih efektif. Hal ini membuat anak-anak dengan intellectual disability menjadi lebih mudah dalam memahami target perilaku yang dimaksudkan. Anak-anak dengan intellectual disability mempelajari suatu hal lebih lama daripada anak-anak sesuasianya, sehingga dengan adanya video untuk modeling ini, subjek dapat mengulangi videonya dengan seksama dan lebih memahami target perilaku pada intervensi ini (Avcioglu, 2013).

Selain itu, menggunakan video sebagai media modelling juga meningkatkan perhatian dan ketertarikan anak-anak dengan intellectual disability (Pierce \& Schreibman, 1994).Menggunakan video sebagai metode modelling juga menambah motivasi subjek dan merupakan sebuah metode yang disukai oleh anak-anak dengan intellectual disability (Schreibman et al., 2000).

Selain menggunakan video modeling, digunakan juga reinforcement positif yang berupa makanan ringan yang sangat disukai subjek dan juga pujian.Pemberian reinforcement positif yang berupa pujian juga diberikan oleh orangtua dan guru subjek.Pemilihan reinforcement yang tepat dalam menangani kasus dengan anak intellectual disability merupakan sebuah hal yang sangat penting karena memiliki pengaruh besar terhadap perubahan keterampilan sosial yang dimiliki oleh subjek.Pemilihan hal disukai oleh subjek memberikan perubahan keterampilan subjek. Melalui pemberian reinforcement yang disukai tersebut, anak akan merasa terpacu dan bersemangat untuk terus melakukan hal-hal baru yang dipelajarinya dan menerapkannya dalam kehidupan sehari-harinya (Murpratiwi \&Tjakrawiralaksana, 2018).

Pemberian pujian sebagai bentuk reinforcement sosial yang diberikan secara terus-menerus kepada anak dengan intellectual disability efektif memberikan pengaruh pada meningkatnya keterampilan sosial anak. Anak dengan intellectual disability sangat responsif terhadap pujian dan dukungan. Pujian, hadiah, dan dukungan ini membangun kekuatan dan semangat dalam diri anak dengan intellectual disability untuk terus berlatih atau belajar sesuatu yang baru.Pemberian pujian yang merupakan reinforcement sosial merupakan teknik yang paling efektif yang dapat digunakan bersamaan dengan metode behavior lainnya (Adibsereshki, Abkeenar, Ashoori, \& Mirzamani, 2014). Pemberian reinforcement positif juga merupakan cara yang mudah dan sederhana untuk membentuk perilaku anak dengan intellectual disability (Newcomer, 2009; Simonsen et al, 2008).

Subjek anak dengan disabilitas intelektual membutuhkan pengawasan dan dorongan yang lebih.Sehingga, harus terdapat tindak lanjut setelah intervensi selesai.Hal tersebut bertujuan agar perubahan perilaku pada subjek dapat menetap. Orangtua dan guru sebaiknya memberikan kesempatan bagi anak untuk dapat mengembangkan dan belajar tentang keterampilan sosial dengan mengajari anak dan mndorong anak untuk berinteraksi dengan teman sebayanya.

\section{Kesimpulan}

Intervensi menggunakan pendekatan teknik reinforcement positive dan juga modeling mampu meningkatkan keterampilan sosial pada anak dengan intellectual disability.Berdasarkan hasil evaluasi sebelum intervensi dan sesudah intervensi terdapat perubahan.Bahwa subjek setelah intervensi dapat berbicara dengan hati-hati sehingga terdengar lebih jelas.Subjek juga mulai dapat berinteraksi dengan teman-temannya dengan menyapa dan berbicara terlebih 
dahulu.Subjek juga dapat berbicara dengan nada bicara yang lebih baik dan lebih sesuai.

\section{Referensi}

Adibsereshki, N., Abkenar, S. J., Ashoori, M., \& Mirzamani, M. (2015) The effectiveness of using reinforcements in the classroom on the academic achievement student with intelectual disabilities. Journal of Intellectual Disabilities, 19(1), 83-93.

American Psychiatric Association. (2013). Diagnostic and statistical manual of mental disorders (5th ed.). Washington, DC: Author.

Avcioglu, Hasan. (2013). Effectiveness of Video Modelling in Training Students with Intellectual Disabilities to Greet People When They MeetEducational Sciences: Theory and Practice. Vol 13(). 12. Charlop-Christy, M. H., Le, L., \& Freeman, K. (2001). A comparison of video modeling with invivo modeling for teaching children with autism. Journal of Autism and Developmental Disorders, 30, 537-552.

Corey, G. 2009. Theory and Practice of Counseling and Psychotheraphy: Eighth Edition. Belmont: Thomson Higher Education.

Gresham, F. M., \& Elliott, S. N. (1990). Social skills rating system manual. Circle Pines, MN: American Guidance Service.

Hallahan, D. P and Kauffman, J. M. 1988. Exceptional Children: Introduction to Special Education. New Jersey: Prentice Hall, Inc.

Martin, G., \& Pear, J. (2007). Behavior Modification: What It Is and How to Do It (8th ed.). Englewood Cliffs, NJ: Prentice Hall.

Merrell, K., \& Gimpel, G. (1998).Social Skills of Children and Adolescents.Conceptualization, Assessment, Treatment. Mahwah, NJ: Lawrence Erlbaum Associates.

Murpratiwi, I. A., Tjakrawiralaksana, M.A. (2018). Prompting and Positive Reinforcement to Improve Dressing Skill in Children With Intellectual Disability. Jurnal Psikologi Teori dan Terapan. 8 (2) 112-123.

Newcomer L (2009) Universal positive behavior support for the classroom. PBIS Newsletter 4(4). Available at: http://www.pbis.org/pbis_newsletter/volume_4/issue4.aspx (accessed 24 September 2009).

Nikopoulos C.K\&Keenan M. (2007). Using video modeling to teach complex social sequences to children with autism.Journal Autism Dev Disord. 37(4):678-93.

Olson, M., \& Hergenhahn, B.R. (2013).Pengantar Teori-Teori Kepribadian Edisi Kedelapan. Yogyakarta: Pustaka Pelajar

Ormrod, Jeanne Ellis. 2009. Psikologi Pendidikan Membantu Siswa Tumbuh dan Berkembang.Jilid 1.Jakarta : Erlangga.

Pierce, K. L \& Schreibman, L. (1994). Teaching Daily Living Skills to Children with Autism in Unsupervised Settings through Pictorial Self-Management. Journal of Applied Behavior Analysis, 27(3): 471-81.

Schreibman, L., Whalen, C., \& Stahmer, A. (2000). The use of video priming to reduce disruptive transition behavior in children with autism. Journal of Positive Behavior Interventions, 2, 3-11.

Simonsen B, Fairbanks S, Briesch A, et al. (2008) Evidence-based practices in classroom management: considerations for research to practice. Education and Treatment of Children 31(3): 351-38 